\title{
Comparative anti-MRSA activities of seven selected Nigerian medicinal plants and phytochemical constituents of Piper guineense (Schum and Thonn.), Curculigo pilosa (Schum and Thonn.) and Chromolaena odorata (King and Robinson).
}

\author{
Maureen Uchechukwu Okwu ${ }^{1}$, Tonye Grace Okorie ${ }^{1}$, Matthias Ikenna Agba ${ }^{2}$, \\ Buniyamin Adesina Ayinde ${ }^{3}$ and Henry Osamuyi Uwumarongie ${ }^{3}$ \\ Department of Biological Sciences, College of Natural and Applied Sciences, Igbinedion University, Okada. \\ P.O. Box 0006, Edo State, Nigeria ${ }^{1}$. \\ Department of Medical Microbiology, College of Health Sciences, Igbinedion University Teaching Hospital, \\ Okada ${ }^{2}$. \\ Department of Pharmacognosy, Faculty of Pharmacy, University of Benin, Edo State, Nigeria ${ }^{3}$.
}

\begin{abstract}
The aims of this study were to compare the anti-MRSA activities of Ageratum conyzoides, Bryophyllum pinnatum, Piper guineense, Peperomia pellucida, Ocimum gratissimum, Chromolaena odorata and Curculigo pilosa and to determine the phytochemical constituents of the bioactive plants. Preliminary antibacterial susceptibility test using $25 \mathrm{mg} / \mathrm{ml}$ and $50 \mathrm{mg} / \mathrm{ml}$ concentrations of the aqueous and ethanolic extracts of the plants on eight clinical MRSA isolates showed no anti-MRSA activity with A. conyzoides, $B$. pinnatum, $P$. pellucida and $O$. gratissimum. Activities were recorded with $C$. odorata, $P$. guineense and $C$. pilosa. Phytochemical analysis of the aqueous, ethanolic and hexane extracts of the three bioactive plants selected revealed the presence of: carbohydrates, reducing sugars, saponins, tannins, alkaloids, flavonoids and steroids while in the hexane extracts only steroids were obtained. Antibacterial activities of the aqueous, ethanolic and hexane extracts of the three plants on seven MRSA and four MSSA were: C. odorata: 9.29 $\pm 1.25 \mathrm{~mm}$ (MIC, $12.5 \mathrm{mg} / \mathrm{ml}$ ), $12.17 \pm 1.38 \mathrm{~mm}$ (MIC, $12.5 \mathrm{mg} / \mathrm{ml}$ ), $5.06 \pm 1.17 \mathrm{~mm}$ (MIC, $25 \mathrm{mg} / \mathrm{ml}) ;$ P. guineense: $1.53 \pm 0.59 \mathrm{~mm}$ (MIC, $50 \mathrm{mg} / \mathrm{ml}$ ), $6.34 \pm 1.19 \mathrm{~mm}(\mathrm{MIC}, 25 \mathrm{mg} / \mathrm{ml}$ ), $3.41 \pm 1.03 \mathrm{~mm}(\mathrm{MIC}, 12.5 \mathrm{mg} / \mathrm{ml})$ and $C$. pilosa: $2.14 \pm 0.69 \mathrm{~mm}$ (MIC, $50 \mathrm{mg} / \mathrm{ml}$ ), $1.72 \pm 0.60 \mathrm{~mm}$ (MIC, $50 \mathrm{mg} / \mathrm{ml}$ ) with no activity for its hexane extract respectively. The results suggest the need to isolate and evaluate the active constituents of $C$. odorata as the most efficacious plant for the development of novel chemotherapeutic agents for the effective treatment of MRSA infections.
\end{abstract}

Keywords: Methicillin-resistant S. aureus (MRSA), Methicillin-susceptible S. aureus (MSSA), Minimum inhibitory concentration (MIC), Phytochemical.

\section{Introduction}

Methicillin-resistant Staphylococcus aureus (MRSA) is a strain of the bacterium S. aureus. It is characterized by antimicrobial resistant to methicillin and many other chemotherapeutic agents (1). MRSA causes skin, soft tissues and invasive infections $(2,3,4)$. The treatment of these infections has become more problematic since MRSA is increasingly resistant to as many as twenty different antimicrobial compounds. These include the biocides that represent most of the available drug classes (5). MRSA infections have now become a major public health concern and its prevalence is also increasing globally (6).

Long before mankind discovered the existence of microbes, the idea that certain plants have healing potentials and that they contained antimicrobial properties was well accepted. These plants constitute an effective source of both traditional and modern medicines $(7,8)$. In Nigeria where there is a low access to basic primary health care in many parts of the country, consumers' preference for consultations with traditional herbal practitioners is increasing. Therefore, the medicinal plants used in traditional medicine need to be investigated for a better understanding of their properties, safety and efficiency (9).

Bryophyllum pinnatum is a member of the family Crassulaceae. In southern Nigeria, it is used to facilitate the dropping and healing of placenta wound of newly born babies. It is also used for the treatment of ear-ache, cough, diarrhea, dysentery, abscesses, ulcers, insect bites, epilepsy, heart-troubles, arthritis and wounds $(10,11)$.

Ageratum conyzoides (Linn.) is a small herbaceous plant in the family Asteraceae. It has antibacterial, anti-inflammatory, wound healing, spasmolytic, antitumour, and allelopathic activities $(12,13,14,15,16)$.

Curculigo pilosa (Schum and Thonn.) belongs to the family Hypoxidaceae. In Nigeria, the use of the rhizomes include treatment of leaukemia, gonorrhea and cough $(11,17)$. 
Piper guineense is a member of the family Piperaceae. It is used to spice varied dishes for women in post-natal period and it has antibacterial effects on E. coli and S. aureus $(18,19,20)$.

Peperomia pellucida belongs to the family Piperaceae. The plant has been used for treating multitude of diseases such as: abdominal pain, gout, headache, renal disorders, acne, boils and abscesses and rheumatic joint pain. It has also been shown to have antibacterial activities against B. subtilis, E. coli, P. aeruginosa and S. aureus $(21,22,23)$.

Ocimum gratissimum is a member of the family Lamiaceae. In southern Nigeria and beyond, the leaves are used for the treatment of diarrhea, malaria, skin infections, conjunctivitis, bronchitis, cough and convulsive disorders (24).

Chromolaena odorata (King and Robinson) is a member of the family Asteraceae. In traditional medicine, it is used as antispasmodic, antiprotozoal, antitrypanosomal, astringent, diuretic and hepatotropic agents $(25,26)$.

This work was designed to compare the anti-MRSA activities of the above seven selected Nigerian medicinal plants and to determine the phytochemical constituents of the bioactive plants.

\subsection{Identification of MRSA and MSSA isolates}

\section{Materials and Methods}

Eleven (11) clinical isolates (7 MRSA and 4 MSSA) of S. aureus obtained from: University of Benin teaching hospital (UBTH), Benin, University of Nigeria teaching hospital (UNTH), Enugu, Jos University teaching hospital (JUTH), Jos and Cherith Diagnostic laboratory (CDL), Lagos, Nigeria were used. The MRSA and MSSA (methicillin-susceptible S. aureus) isolates were identified using standard microbiological methods which included colonial morphology, Gram's staining, biochemical and oxacillin screen agar tests $(27,28)$.

\subsection{Plant samples collection and identification}

Fresh leaves of A. conyzoides, C. odorata, B. pinnatum, P. pellucida and O. gratissimum were collected from their natural habitats in Igbinedion University, Okada environs, Edo State, Nigeria in the month of September, 2012. Fresh rhizomes of C. pilosa and seeds of P. guineense were purchased from a local market in Benin City, Nigeria at the same period. The plant parts selected in this study were according to the parts commonly used in the locality for traditional medicine. The samples were identified and authenticated in the Department of Botany, University of Benin, Edo State and Forestry Research Institute of Nigeria (FRIN). Voucher specimens were deposited in the herbarium.

\subsection{Preparation of plant materials}

The leaves, seeds and rhizomes of the plants were thoroughly washed with tap water to remove adhering dirt. The rhizomes were cut into pieces and all the plant materials were air-dried for several days. The dried samples were ground into powder using a clean mortar, pestle and a grinding machine (Chelmsford, England), weighed and kept in air-tight containers for further use.

\subsection{Aqueous extraction of plant samples}

A weight of $1.5 \mathrm{~kg}$ of each powdered plant material was macerated with distilled hot water in a blender. Each extract was filtered and the process repeated until all soluble compounds had been extracted as judged by loss of colour of the filtrates. The filtrates were further filtered with sterile filter paper (Whatman no. 1) into conical flasks and transferred into the sample holder of the rotary vacuum evaporator (Cole-Parmer, Japan) where the extract was concentrated to dryness at a temperature of $100{ }^{\circ} \mathrm{C}$ and then air-dried to constant weight (29). The extracts were sterilized under UV light for 2-3 hours before refrigerated at $4{ }^{0} \mathrm{C}$ for further use (20, 30).

\subsection{Ethanol extraction}

The same procedure of extraction as above was done with $70 \%$ ethanol and each extract was concentrated to dryness in a rotary vacuum evaporator at $40{ }^{\circ} \mathrm{C}$ and then air-dried to constant weight. The extracts were sterilized and refrigerated at $4{ }^{\circ} \mathrm{C}$ for further use (30).

\subsection{Hexane extraction}

The same procedure as above was done with redistilled hexane (Kermel) and the extracts were concentrated to dryness at $40{ }^{\circ} \mathrm{C}$, sterilized and refrigerated at $4{ }^{\circ} \mathrm{C}$.

\subsection{Phytochemical Screening}

The aqueous, ethanol and hexane extracts were screened using standard phytochemical methods $(31,32)$ 


\subsection{Screening of plant extracts for anti-MRSA activity}

The plant extracts were screened for anti-MRSA activity using the agar well diffusion technique. Mueller Hinton agar plates were prepared and with a sterile cork borer of $10 \mathrm{~mm}$ diameter, six wells were bored at equidistant after inoculation on each plate a standardized inoculum of $1-2 \times 10^{8} \mathrm{cfu} / \mathrm{ml}$ (compared with 0.5 McFarland standard) of the isolate each. The $5^{\text {th }}$ and $6^{\text {th }}$ wells served as positive and negative controls. Sterile distilled water in the case of soluble extracts and dimethyl sulfoxide (Kermel) for insoluble extracts of the plants served as the negative controls. Ciprofloxacin ( $1 \mathrm{mg} / \mathrm{ml}$; Sigma-Aldrich, China) was used as the positive control. Each plant extract was reconstituted with sterile distilled water (dimethyl sulfoxide was also used for insoluble extracts) and serially diluted using double-fold dilution. A $0.2 \mathrm{ml}$ of each prepared concentration of the plant extracts was aseptically introduced into wells $1-4$. The plates were left on the table for 40 minutes for pre-diffusion, followed by an overnight incubation at $37{ }^{\circ} \mathrm{C}$. Zones of inhibition were measured in millimeters (33). The minimum inhibitory concentration (MIC) in $\mathrm{mg} / \mathrm{ml}$ in this study was taken as the lowest concentration of each extract that inhibited the isolates (20).

\subsection{Statistical analysis}

The data generated were analyzed using non-parametric and parametric T-test, analysis of variance and Duncan's multiple range tests which were used to establish significant differences where applicable. Statistical package for Social Sciences (SPSS), version 20.0 was used.

\section{Results}

The seven selected Nigerian medicinal plants tested against eight MRSA isolates were: Ageratum conyzoides, Bryophyllum pinnatum, Piper guineense, Curculigo pilosa, Peperomia pellucida, Ocimum gratissimum and Chromolaena odorata. All the isolates showed resistant to 25 and $50 \mathrm{mg} / \mathrm{ml}$ of ethanolic and aqueous extracts of A. conyzoides, B. pinnatum, P. pellucida and O. gratissimum. For C. odorata, $75 \%(6 / 8)$ of the isolates showed susceptibility at $50 \mathrm{mg} / \mathrm{ml}$ and $62.5 \%(5 / 8)$ at $25 \mathrm{mg} / \mathrm{ml}$ for both the ethanolic and aqueous extracts. For P. guineense, $75 \%(6 / 8)$ were susceptible at $50 \mathrm{mg} / \mathrm{ml}$ and $12.5 \%(1 / 8)$ at $25 \mathrm{mg} / \mathrm{ml}$ for both extracts. For C. pilosa, $37.5 \%$ (3/8) were susceptible at $50 \mathrm{mg} / \mathrm{ml}$ only for the two extracts (Table 1). These three plants (C. odorata, P. guineense and C. pilosa) with anti-MRSA activities (Table 1) were selected for further analysis.

The weight of C. odorata, P. guineense and C. pilosa used was each $1.5 \mathrm{~kg}$ before each extraction. The percentage yield after extraction with hot distilled water was highest for C. odorata with $9.0 \%$ (135 g), followed by P. guineense with $8.1 \%(121.5 \mathrm{~g})$ and least for C. pilosa with $2.1 \%(31.5 \mathrm{~g})$. When extracted with $70 \%$ ethanol, the percentage yield was highest for C. odorata with $11.2 \%(168 \mathrm{~g})$, followed by P. guineense with $10.1 \%(151.5 \mathrm{~g})$ and least for C. pilosa with $3.0 \%$ (45 g). For hexane plant extracts, the percentage yield was highest for P. guineense with $18.1 \%(271.5 \mathrm{~g})$, followed by C. odorata with $12.1 \%(181.5 \mathrm{~g})$ and least for C. pilosa with $1.0 \%$ (15 g) (Table 2).

Phytochemical analysis was carried out on the aqueous, ethanolic and hexane extracts of the three plants (Table 3). Carbohydrates, reducing sugars, saponins, tannins, alkaloids, steroids and flavonoids were present while anthraquinone and cyanogenetic glycosides were absent in the aqueous and ethanolic extracts of the three plants. Only steroid was present in the hexane extracts of the three plants.

The aqueous, ethanolic and hexane extracts of C. odorata, P. guineense and C. pilosa were tested for antibacterial activities on eleven (7 MRSA and 4 MSSA) S. aureus isolates in triplicates at varying concentrations of $12.5-100 \mathrm{mg} / \mathrm{ml}$. The control strain S. aureus NCIB 8588 was included (Table 4). For the aqueous extracts of the three plants, the mean value for $\mathrm{C}$. odorata was the highest with $9.29 \pm 1.25 \mathrm{~mm}, 2.14 \pm$ $0.69 \mathrm{~mm}$ for C. pilosa and $1.53 \pm 0.59 \mathrm{~mm}$ for P. guineense. The least MIC value for C. odorata was $12.5 \mathrm{mg} / \mathrm{ml}$ while $50 \mathrm{mg} / \mathrm{ml}$ for C. pilosa and P. guineense.

Table 1. Comparative anti-MRSA activities of seven medicinal Nigerian plants on MRSA isolates

\begin{tabular}{lll}
\hline Plant samples & \multicolumn{2}{c}{$\begin{array}{c}\text { Frequency/Percentage }(\%) \text { of } 8 \mathrm{MRSA} \text { isolates. } \\
\text { Concentration of extracts }(\mathrm{mg} / \mathrm{ml})\end{array}$} \\
\hline Ageratum conyzoides & 50 & 0 \\
Curculigo pilosa & 0 & 0 \\
Chromolaena odorata & $3(37.5 \%)$ & $5(62.5 \%)$ \\
Piper guineense & $6(75 \%)$ & $1(12.5 \%)$ \\
Bryophyllum pinnatum & $6(75 \%)$ & 0 \\
Peperomia pellucida & 0 & 0 \\
Ocimum gratissimum & 0 & 0 \\
\hline
\end{tabular}


Table 2. Yield of aqueous, ethanolic and hexane extracts of the three plants with anti-MRSA activities.

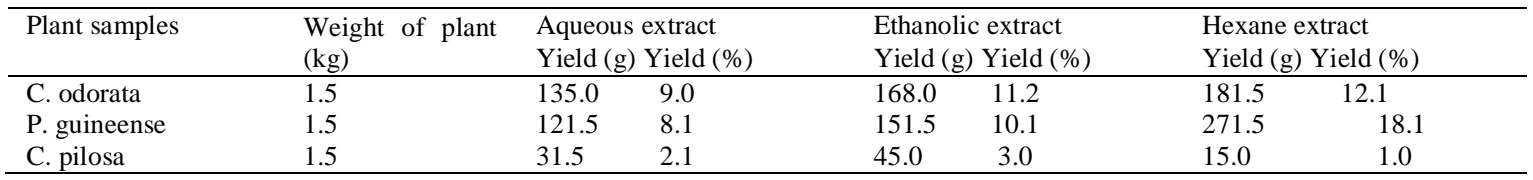

Table 3. Phytochemical constituents of aqueous, ethanolic and hexane extracts of plants with anti-

\begin{tabular}{|c|c|c|c|c|c|c|c|c|c|}
\hline \multirow{2}{*}{$\begin{array}{l}\text { Phytochemical } \\
\text { constitueunts }\end{array}$} & \multicolumn{3}{|c|}{ Aqueous extract } & \multicolumn{3}{|c|}{ Ethanolic extract } & \multicolumn{3}{|c|}{ Hexane extract } \\
\hline & C. o & P. $g$ & C. $p$ & C. $\mathrm{o}$ & P. $g$ & C. $p$ & C. o & P. $g$ & C. $\mathrm{p}$ \\
\hline $\begin{array}{l}\text { Carbohydrates } \\
\text { Reducing }\end{array}$ & + & + & + & + & + & + & - & - & - \\
\hline $\begin{array}{l}\text { sugars } \\
\text { Anthraquinone }\end{array}$ & + & + & + & + & + & + & - & - & - \\
\hline Glycosides & - & - & - & - & - & - & - & - & - \\
\hline Saponins & + & + & + & + & + & + & - & - & - \\
\hline Tannins & + & + & + & + & + & + & - & - & - \\
\hline Alkaloids & + & + & + & + & + & + & - & - & - \\
\hline Steroids & + & + & + & + & + & + & + & + & + \\
\hline $\begin{array}{l}\text { Flavonoids } \\
\text { Cyanogenetic }\end{array}$ & + & + & + & + & + & + & - & - & - \\
\hline Glycosides & - & - & - & - & - & - & - & - & - \\
\hline
\end{tabular}

There was a highly significant difference between the antibacterial activity of C. odorata to C. pilosa and P. guineense $(\mathrm{p}<0.01)$. There was no significant difference between the activities of C. pilosa and P. guineense ( $p>0.05)$. For the ethanolic extracts of the three plants, the mean values were: $12.17 \pm 1.38 \mathrm{~mm}, 6.34$ $\pm 1.19 \mathrm{~mm}$ and $1.72 \pm 0.60 \mathrm{~mm}$ and the least MIC values were: $12.5 \mathrm{mg} / \mathrm{ml}, 25 \mathrm{mg} / \mathrm{ml}$ and $50 \mathrm{mg} / \mathrm{ml}$ for C. odorata, P. guineense and C. pilosa respectively. There were significant differences in the activities of the three plants $(\mathrm{p}<0.05)$. The mean values for the hexane extracts of $C$. odorata and $P$. guineense were $5.06 \pm 1.17 \mathrm{~mm}$ and $3.41 \pm 1.03 \mathrm{~mm}$ with least MIC values of $25 \mathrm{mg} / \mathrm{ml}$ and $12.5 \mathrm{mg} / \mathrm{ml}$ respectively. There was significant difference in activities between $\mathrm{C}$. odorata and P. guineense hexane extracts $(\mathrm{p}<0.05)$. C. pilosa hexane extract showed no activity. Table 5 shows the susceptibility of MRSA and MSSA to the aqueous, ethanolic and hexane extracts of the three plants. There was no significant difference in the activities of the extracts of the three plants between MRSA and MSSA isolates ( $p>0.05)$.

\begin{tabular}{|c|c|c|c|c|c|c|c|c|c|}
\hline \multirow[t]{2}{*}{ Plant sample } & \multicolumn{3}{|c|}{ Aqueous extract } & \multicolumn{3}{|c|}{ Ethanolic extract } & \multicolumn{2}{|c|}{ Hexane extract } & \multirow[b]{2}{*}{$\% \mathrm{MIC}(\mathrm{mg} / \mathrm{ml}$} \\
\hline & $\mathrm{mv}$ & se & $\% \mathrm{MIC}(\mathrm{mg} \mathrm{ml})$ & $\mathrm{mv}$ & se & $\% \mathrm{MIC}(\mathrm{mg} \mathrm{ml})$ & $\mathrm{mv}$ & se & \\
\hline C. odorata & $9.29^{2}$ & $=1.25$ & $9.1 \%(12.5)$ & $12.17^{2}$ & \pm 1.38 & $27.3 \%(12.5)$ & $5.06^{2}$ & $=1.17$ & $10 \%(25)$ \\
\hline P. guineense & $1.53^{b}$ & $=0.59$ & $18.2 \%(50)$ & $6.34^{b}$ & \pm 1.19 & $18.2 \%(25)$ & $3.41^{b}$ & $=1.03$ & $10 \%(12.5)$ \\
\hline C. pilosa & $2.14^{b}$ & $=0.69$ & $9.1 \%(50)$ & $1.72^{\circ}$ & $=0.60$ & $9.1 \%(50)$ & $0.00^{6}$ & $=0.00$ & 0.00 \\
\hline
\end{tabular}

Key: $\%=$ percentage of isolates (MRSA \& MSSA) with; MIC = minimum inhibitory concentration; se $=$ standard error; mv = mean value in millimeters Values with the same letters are not significantly different $(p>0.05)$ in activity while different letters are significantly different $(p<0.05)$ in activity. MRSA = methicillin-resistant $S$, aureus; MSSA = methicillin-resistant susceptible S. aureus

\begin{tabular}{|c|c|c|c|c|c|c|c|c|c|c|c|c|}
\hline \multirow[t]{3}{*}{ Plant sample } & \multicolumn{4}{|c|}{ Aqueous extract } & \multicolumn{4}{|c|}{ Ethanolic extract } & & \multicolumn{2}{|c|}{ Hexane extract } & \\
\hline & \multicolumn{2}{|c|}{ MRSA } & \multicolumn{2}{|c|}{ MSSA } & \multicolumn{2}{|c|}{ MRSA } & \multicolumn{2}{|c|}{ MSSA } & \multicolumn{2}{|c|}{ MRSA } & \multicolumn{2}{|c|}{ MSSA } \\
\hline & $\mathrm{mv}$ & se & $\mathrm{mv}$ & se & $\mathrm{mv}$ & se & $\mathrm{mv}$ & se & $\mathrm{mv}$ & se & $\mathrm{mv}$ & se \\
\hline C.odorata & 8.56 & $=1.76$ & 10.16 & $=1.81$ & 10.00 & $=1.89$ & 14.78 & $=1.90$ & 5.43 & \pm 1.78 & 4.70 & \pm 1.57 \\
\hline P. guineense & 2.54 & \pm 1.02 & 0.33 & $=0.33$ & 6.79 & $=1.54$ & 6.60 & $=0.94$ & 4.42 & $=1.50$ & 2.60 & $=1.43$ \\
\hline C. pilosa & 2.73 & $=0.97$ & 1.72 & $=0.99$ & 1.75 & $=0.72$ & 1.68 & $=1.01$ & 0.00 & $=0.00$ & 0.00 & $=0.00$ \\
\hline
\end{tabular}

$\mathrm{Key}: \mathrm{mv}=$ mean value in millimetres; se = standard error; $\mathrm{MRSA}=$ methicillin-resistant $\mathrm{S}$. aureus $:$ MSSA = methicillin-susceptible S. aureus

\section{Discussion}

A progressive increase in the prevalence of MRSA all over the world has been reported (34). The prevalence of MRSA in Nigeria usually varies between $33.3 \%$ and $71.2 \%(35,36,37,38)$. MRSA is not only resistant to methicillin but also increasingly to as many as twenty different antimicrobial compounds including 
various biocides, representing most of the available drug classes (5). Therefore, there is a need to search for new, effective, cheap and easily affordable drugs in the management of MRSA infections.

In this study, the preliminary screening for anti-MRSA activity with seven medicinal plants showed resistance (no zone of inhibition) with aqueous and ethanolic extracts of A. conyzoides, B. pinnatum, P. pellucida and O. gratissimum at $25 \mathrm{mg} / \mathrm{ml}$ and $50 \mathrm{mg} / \mathrm{ml}$. However, there were activities with C. odorata, P. guineense and C. pilosa at the same concentrations. This agrees with the previous study of Okwulehie and Akanwa, (39) who reported that the ethanolic extract of the leaves of A. conyzoides did not inhibit the growth of S. aureus at $12.5 \mathrm{mg} / \mathrm{ml}$ and $25 \mathrm{mg} / \mathrm{ml}$ while the activity at $50 \mathrm{mg} / \mathrm{ml}$ was poor. On the contrary, the report of Akinyemi, et al., (7) stated that the aqueous and ethanolic extracts of A. conyzoides showed minimum inhibitory concentration (MIC) of $71 \mathrm{mg} / \mathrm{ml}$ and $43 \mathrm{mg} / \mathrm{ml}$ respectively. Also, Okwonri, et al., (33) reported antibacterial activity of A. conyzoides on S. aureus at $100-12.5 \mathrm{mg} / \mathrm{ml}$.

For B. pinnatum, the result observed in this study agrees with the report of Akinsulire, et al., (40) who stated that the minimum inhibitory concentration (MIC) of aqueous extract of the plant leaves on S. aureus was $128 \mathrm{mg} / \mathrm{ml}$ while Obiukwu and Nwanekwu, (41) reported that the ethanolic extract of the leaves gave activity at $100 \mathrm{mg} / \mathrm{ml}$ on S. aureus.

P. pellucida showed no activity at 25 and $50 \mathrm{mg} / \mathrm{ml}$ in this study. This agrees with the report of Mensah, et al., (42) who stated that $100 \mathrm{mg} / \mathrm{ml}$ aqueous extract of the leaves of P. pellucida had no activity while the ethanolic extract of the same concentration inhibited S. aureus weakly.

O. gratissimum showed no activity also at 25 and $50 \mathrm{mg} / \mathrm{ml}$ in this study. This observation disagrees with the finding of Nwinyi, et al., (20) who reported that the MIC of aqueous and ethanolic extracts of the leaves of the plant on S. aureus were $10 \mathrm{mg} / \mathrm{ml}$ and $2.5 \mathrm{mg} / \mathrm{ml}$ respectively while Akinyemi, et al., (7) reported MIC of $25 \mathrm{mg} / \mathrm{ml}$ and $22.3 \mathrm{mg} / \mathrm{ml}$ respectively. However, the result of this study agrees with the finding of Adebolu and Oladimeji (43) who reported that only the steam distillation extract of O. gratissimum leaves inhibited the growth of S. aureus. They concluded that only the oil from the leaves has antibacterial activity and the resistance of bacteria to the extracts of $\mathrm{O}$. gratissimum may be due to the high volatibility of the oil leading to the escape or evaporation of the oil during boiling. Okigbo, et al., (29) also reported that the inactivity of plant extracts may be due to the age of the plant, extracting solvents, methods of extraction and the time of harvesting plant materials.

In this study, the anti-MRSA activity of the aqueous extract of C. odorata was significantly higher $(\mathrm{p}<$ 0.01 ) than that of $\mathrm{P}$. guineense and C. pilosa. For C. odorata, the least MIC value was $12.5 \mathrm{mg} / \mathrm{ml}$ which inhibited $9.1 \%$ of the MRSA isolates but $50 \mathrm{mg} / \mathrm{ml}$ for P. guineense and C. pilosa which inhibited $18.2 \%$ and $9.1 \%$ of the isolates respectively. The anti-MRSA activity of the ethanolic extract of C. odorata was also significantly higher $(\mathrm{p}<0.05)$ than that of P. guineense and C. pilosa. The least MIC value was $12.5 \mathrm{mg} / \mathrm{ml}$ which inhibited $27.3 \%$ of the MRSA isolates for C. odorata but $25 \mathrm{mg} / \mathrm{ml}$ and $50 \mathrm{mg} / \mathrm{ml}$ for P. guineense and C. pilosa which inhibited $18.2 \%$ and $9.1 \%$ of the isolates respectively. The anti-MRSA activity of the hexane extract of C. odorata was also significantly higher $(\mathrm{p}<0.05)$ than that of P. guineense even though the least MIC value was $25 \mathrm{mg} / \mathrm{ml}$ for $\mathrm{C}$. odorata and $12.5 \mathrm{mg} / \mathrm{ml}$ for P. guineense. The mean value for $\mathrm{C}$. odorata $(5.06 \pm 1.17$ $\mathrm{mm}$ ) was significantly higher than that of P. guineense $(3.41 \pm 1.03 \mathrm{~mm})$. No anti-MRSA activity was observed for the hexane extract of C. pilosa in this study. These observations disagree with the findings of Sukanya, et al., (44) and Nwinyi, et al., (20) who reported that the MIC values of the aqueous extracts of C. odorata and P. guineense were $1 \mathrm{mg} / \mathrm{ml}$ and $10 \mathrm{mg} / \mathrm{ml}$ respectively for S. aureus isolates. Ojo, et al., (45) and Natheer, et al., (46) reported that plant samples collected from different geographic origins with different climates and vegetations show different antibacterial activities.

For the ethanolic extracts, the result in this study disagrees with the findings of Nwinyi, et al., (20) and Sukanya, et al., (44) who reported that the MIC values of ethanolic extracts of C. odorata and P. guineense were $4 \mathrm{mg} / \mathrm{ml}$ and $10 \mathrm{mg} / \mathrm{ml}$ respectively. However, it agrees with the report of Adebayo-Tayo, et al., (47) who reported an activity of C. pilosa on S. aureus at $40 \mathrm{mg} / \mathrm{ml}$.

In comparison, the mean value $12.17 \pm 1.38 \mathrm{~mm}$ (at MIC of $12.5 \mathrm{mg} / \mathrm{ml}$ ) of anti-MRSA activity of the ethanolic extract of $\mathrm{C}$. odorata was the highest of the aqueous, ethanolic and hexane extracts of the three plants in this study. However, statistical analysis showed no significant difference $(p>0.05)$ between the ethanolic and aqueous extracts of $\mathrm{C}$. odorata. The weak anti-MRSA activities of hexane extracts of $\mathrm{C}$. odorata and $\mathrm{P}$. guineense are in agreement with the report of Rojas, et al., (48).

Analysis of the chemical components of the three plants revealed that the aqueous and ethanolic extracts of the three plants contained the same phytochemical constituents which were: saponins, tannins, alkaloids, steroids and flavonoids in this study. The hexane extracts of the three plants revealed the presence of steroids only. These findings agree with the reports of Igbo, et al., (49). However, they reported the presence of cyanogenetic and cardiac glycosides which were absent in this study. Therefore, the aqueous and ethanolic extracts of the three plants contained many bioactive compounds which have been reported by Adebayo-Tayo, et al., (47) to contribute to the antimicrobial potentials of plants. The weak activities of hexane extracts of C. 
odorata, P. guineense and no activity for C. pilosa could be due to the presence of only steroids. Nwabueze and Okocha, (50) and Das, et al., (51) reported that hexane is used as a solvent to extract non-polar constituents of plants by several workers to obtain antimicrobial crude extracts. In particular, P. guineense followed by C. odorata hexane extracts gave the highest yields of extractable substances in this study. This observation indicates that hexane extraction is a good method for the extraction of steroids in the three plants used in this study.

\section{Conclusion}

The comparative anti-MRSA activities of seven selected Nigerian medicinal plants were determined. A. conyzoides, B. pinnatum, P. pellucida and O. gratissimum showed no MRSA activities while C. odorata, P. guineense and C. pilosa showed activities. However, the aqueous and ethanolic extracts of C. odorata were considered the most efficacious of the seven medicinal plants. This suggests a need to isolate and evaluate the active constituents of $\mathrm{C}$. odorata which can be used for the development of novel chemotherapeutic agents for the effective treatment of MRSA infections.

\section{Acknowledgements}

Special thanks go to Mr. Mitsan Olley in the Department of Pathology, Igbinedion University Teaching Hospital, Okada for his assistance in this work.

\section{References}

[1]. S. Mansouri, and M. Khaleghi, Antibacterial resistance pattern and frequency of methicillin-resistant S. aureus (MRSA), Iranian Journal of Medical Science, 22, 1997, 93.

[2]. Centres for Disease Control and Prevention (CDC). J. Watson, R. Jones, C. Cortes, and S. Gerber, Community-associated methicillin-resistant S. aureus infection among healthy newborns in Chicago and Los Angelos County, 2004, Morbidity and Mortality Weekly Report, 55(12), 2006, 329-332.

[3]. S. Jamart, O. Denis, A. Deplano, G. Tragas, A. Vandergheynst, D. DeBels, and J. Devriendt, Methicillin-resistant S. aureus toxic shock syndrome, Emerging Infectious Diseases, 11 (4), 2005, 636-637.

[4]. G. Durand, M. Bes, H. Meugnier, M. Enright, F. Forey, N. Liassine, A. Wenger, K. Kikuchi, and G. Lina, Detection of new methicillin-resistant S. aureus clones containing the toxic shock syndrome toxin1 gene responsible for hospital- and communityacquired infections in France, Journal of Clinical Microbiology, 44, 2006, 847-853.

[5]. S. Jenson, and B. Lyon, Genetics of antimicrobial resistance in Staphylococcus aureus, Future Microbiology, 4, $2009,565-582$.

[6]. Q. Peng, B. Hou, S. Zhou, Y. Huang, D. Hua, F. Yoa, and Y. Qian, Staphylococcal cassette chromosome mec (SCCmec) analysis and antimicrobial susceptibility profiles of methicillin resistant S. aureus (MRSA) isolates in a teaching hospital, Shontou, China, African Journal of Microbiology Research, 4(9), 2010, $844-848$.

[7]. K. Akinyemi, O. Oladapo, C. Okwara, C. Ibe, and K. Fasure, Screening crude extracts of six medicinal plants used in South-West Nigerian unorthodox medicine for anti-methicillin-resistant S. aureus activity, BMC Complementary and Alternative Medicine, 5, $2005,6$.

[8]. M. Sermakkani, and V. Thangapandian, Gas chromatography - Mass Spectrometry analysis of Cassia italic leaf methanol extract, Asian Journal of Pharmaceutical and Clinical Research, 5(2), 2012, 90 - 94.

[9]. J. Ellof, Which extractant should be used for the screening and isolation of antimicrobial components from plants, Journal of Ethnopharmacology, 60, 1998, 1 - 6.

[10]. L. S. Gill, Ethnomedicinal uses of plants in Nigeria (Nigeria: University of Benin Press, 1992), 276.

[11]. T. Odugbemi, and O. Akinsuline, Pictures of medicinal plants, in T. Odugbemi (Ed.), Outlines and Pictures of Medicinal Plants from Nigeria, (Akoka, Yaba, Lagos: University of Lagos Press, 2006), 164-255.

[12]. M. Silva, F. Capaz, and M. Vale, Effects of the water soluble fraction from leaves of Ageratum conyzoides on smooth muscle, Phytotherapy Research, 14(2), 2000, $130-132$.

[13]. C. Kong, F. Hu, and X. Xu, Allelopathic potential and chemical constituents of volatiles from Ageratum conyzoides under stress. Journal of Chemical Ecology, 28(6), 2002, 1773 - 1782.

[14]. A. Shiriwaikar, P. Bhilegoankar, S. Malini, S. and J. Kumar, The gastroprotective activity of the ethanol extract of Ageratum conyzoides, Journal of Ethnopharmacology, 86(1), 2003, 117 - 121.

[15]. O. Oladejo, I. Imosemi, F. Osuagwu, O. Oluwa Dara, A. Aiku, O. Adewoyin, and O. Ekpo, Enhancement of cutaneous wound healing by methanolic extracts of Ageratum conyzoides in the wistar rat, African Journal of Biomedical Research, 6(1), 2003, 27 31.

[16]. T. Shekhar, and G. Anju, A comprehensive review on Ageratum conyzoides Linn. (Goat weed), International Journal of Pharmaceutical Phytopharmacology Research, 1(6), 2012, 391-395.

[17]. I. Gbadamosi, and A. Egunyomi, Phytochemical screening and in vitro anticandidal activity of extracts and essential oil of Curculigo pilosa (Schum and Thonn) Engl. Hypoxidaceae, African Journal of Biotechnology, 9(8), 2010, 1236 - 1240.

[18]. N. Ukwandu, A. Odaibo, T. Okorie, and O. Nmorsi, Molluscicidal effect of Piper guineense, African Journal of Traditional Complimentary Alternative Medicine, 8(4), 447 - 451.

[19]. C. Obafemi, T. Sulaimon, D. Akinpelu, and T. Olugbade, Antimicrobial activity of extracts and a germacranolide-type of sesquiterpene lactone from Tithonia diversifolia leaf extract, African Journal Biotechnology, 12, 2006, 1254-1258.

[20]. O. Nwinyi, N. Chinedu, O. Ajani, and K. Oguniran, Antibacterial effects of extracts of Ocimum gratissimum and Piper guineen se on Escherichia coli and S. aureus, African Journal of Food Science, 3(1), 2009, 22-25.

[21]. A. Bojo, E. Albano-Garcia, and G. Possidio, The antibactriqal activity of Peperomia pellucida (L.), Asian Life Science, 3, 1994, 3544.

[22]. P. Aziba, D. Bass, and Y. Elegbe, Pharmacological investigation of Ocimum gratissimum in rodent for analgesic activity, Phytotherapy Research, 13, 1999, 427 - 429.

[23]. M. Khan, and A. Omoloso, Antibacterial activity of Hygrophila stricta and Peperomia pellucida, Fitoterapia, 73(3), $2002,251-254$. 
[24]. C. Okoli, A. Ezike, O. Agwagah, and P. Akah, Anticonvulsant and anxiolytic evaluation of leaf extracts of Ocimum gratissimum, a culinary herb, Pharmacognosy Research, 2(1), 2010, $36-40$.

[25]. T. Phan, L. Wang, P. See, R. grayer, S. Chan, and S. See, Phenolic compounds of Chromolaena odorata protect cultured skin cells from oxidative damage: implication for cutaneous wound healing, Biological Pharmacy Bulletin, 24, 2001, 1373 - 1379.

[26]. A. Akinmoladu, E. Ibudun, and I. Danologe, Phytochemical constituents and antioxidant properties of extracts from the leaves of Chromolaena odorata, Scientific Research Essays, 2(6), 2007, 191-194.

[27]. M. Cheesbrough, Staphylococcus, in M. Cheesbrough (Ed.), District of Laboratory Practice in Tropical Countries (South Africa: Cambridge University Press, 2004), 157-158.

[28]. A. Kumurya, A. Uba, O. Oyamaye, and I. Yusif, Comparison of different laboratory methods for detection of methicillin resistant S. aureus (MRSA), International Journal of Biomedical and Health Sciences, 4(4), 2008, 1-4.

[29]. R. Okigbo, C. Mbajaka, and C. Njoku, Antimicrobial potential of (Uda) Xylopia aethopica and Ocimum gratissimum on some pathogens of man, International Molecular Medicine and Advanced Science, Pakistan, 1(4), 2005, 392-394.

[30]. P. Tiwari, B. Kumar, M. Kaur, G. Kaur, and H. Kaur, Phytochemical screening and extraction: A review, Internationale PharmaceuticaSciencia, 1(1), 2011, 98 - 106.

[31]. W. C. Evans, Trease and Evans Pharmacognosy, W. B. Saunders (Ed.), (Philadelphia, 2002) 3, 338.

[32]. A. Sofowora, Medicinal plants and traditional medicine in Africa, ( John Wiley and Sons Limited, 1982) 128-145.

[33]. A. Okwonri, C. Dina, S. Junaid, I. Okeke, J. Adetunji, and A. Olabode, Antibacterial activities of Ageratum conyzoides extracts on selected bacterial pathogens, The International Journal of Microbiology, 4(1), 2007, From, http://www.ispub.com/journal/the_internet_journal_of_microbiology/volume_4_number_1_26/article/antibacterial_activities_of_ag eratum_conyzoides_extract_on_selected_bacterial_pathogens.html

[34]. O. Fayomi, E. Oyediran, A. Adeyemo, and O. Oyekale, Prevalence and antibiotic resistance pattern of methicillin-resistant S. aureus among in-patients at a tertiary health facility in Ido-Ekiti, Nigeria, The Internet Journal of Laboratory Medicine, 4, 2011, 2.

[35]. S. Taiwo, B. Onile, and A. Akanbi, Methicillin-resistant S. aureus (MRSA) in Ilorin, Nigeria, African Journal of Clinical and Experimental Microbiology, 5(2), 2004, 189-197.

[36]. A. Onanuga, A. Oyi and J. Onaolapo, Prevalence and susceptibility pattern of methicillin- resistant S. aureus isolates among healthy women in Zaria, Nigeria, African Journal of Biotechnology, 4(11), 2005, 1321 - 1324.

[37]. H. Tiwari, D. Sapkota, and M. Sen, High prevalence of multidrug-resistant methicillin-resistant S. aureus in a tertiary care hospital in Northern India. Infection and Drug Research, 1, 2008, $57-61$.

[38]. M. Okwu, T. Okorie, O. Mitsan, and E. Osakue, Prevalence and comparison of three methods for detection of methicillin-resistant S. aureus (MRSA) isolates in tertiary health institutions in Nigeria, Canadian Open Biological Sciences Journal, 1(1), 2014, 1-12.

[39]. I. Okwulehie, and F. Akanwa, Antimicrobial activity of ethanol extract of four indigenous plants from Southeastern Nigeria, ARPN Journal of Science and Technology, 3(4), 2013, 350-355.

[40]. O. Akinsulire, I. Aibinu, T. Adenipekun, T. Adelowotan, and T. Odugbemi, In vitro antimicrobial activity of crude extracts from plants, Bryophyllum pinnatum and Kalanchoe crenata, African Journal of Traditional and Complimentary Alternative Medicine, 4(3), 2007, $338-344$.

[41]. C. Obiukwu, and K. Nwanekwu, Evaluation of the antimicrobial potentials of thirty-five medicinal plants from Nigeria, International Science Research Journal, 2, 2010, 48 - 51.

[42]. J. Mensah, J. Ihenyem, and M. Okhiure, Nutritional, phytochemical and antimicrobial properties of two wild aromatic vegetables from Edo State, Journal of Natural Products and Plant Resources, 3(1), 2013, 8 - 14.

[43]. T. Adebolu, and S. Oladimeji, Antimicrobial activity of leaf extract of Ocimum gratissimum on selected diarrhea causing bacteria in Southwestern Nigeria, African Journal of Biotechnology, 4(7), 2005, $682-684$.

[44]. S. Sukanya, J. Sudisha, P. Hariprasad, S. Niranjana, H. Prakash, and S. Fathima, Antimicrobial activity of leaf extracts of Indian medicinal plants against clinical and phytopathogenic bacteria, African Journal of Biotechnology, 8(23), 2009, 6677 - 6682.

[45]. O. Ojo, A. Ajayi, and I. Anibijuwon, Antibacterial properties of extracts of some Nigerian spices, Journal of Pure and Applied Microbiology, 1(1), 2007, $119-122$.

[46]. S. Natheer, C. Sekar, P. Amutharaj, M. Rahman, and K. Khan, Evaluation of antibacterial activity of Morinda citrifolia, Vitex trifolia and Chromolaena odorata, African Journal of Pharmacy and Pharmacology, 6(11), 2012, 783 - 788.

[47]. B. Adebayo-Tayo, A. Adegoke, A. Okoh, and K. Ajibesin, Rationalizing some medicinal plants used in treatment of skin diseases, African Journal of Microbiology Research, 4(10), 2010, 958 - 963.

[48]. J. Rojas, V. Ochoa, S. Ocampo, and J. Munoz, Screening for antimicrobial activity of ten medicinal plants used in Colombian folkloric medicine: A possible alternative in the treatment of non-nosocomial infections, BMC Complementary and Alternative Medicine, 6, 2006, 2, from: http://creativecommons.org/licenses/by/2.0.

[49]. M. Igboh, C. Ikewuchi, and C. Ikewuchi, Chemical profile of Chromolaena odorata L. (King and Robinson) leaves, Pakistan Journal of Nutrition, 8(5), 2009, 521-524.

[50]. T. Nwabueze, and K. Okocha, Extraction performances of polar and non-polar solvents on the physical and chemical indices of African breadfruit (Treculia africana) seed oil, African Journal of Food Science, 2, 2008, $119-125$.

[51]. K. Das, R. Tiwari, and D. Shrivastava, Techniques for evaluation of medicinal plant products as antimicrobial agent: current methods and future trends, Journal of Medicinal Plants Research, 4(2), 2010, $104-111$. 